\title{
PENGARUH BERMAIN PERAN TERHADAP INTERAKSI SOSIAL ANAK USIA DINI
}

\section{Annisa Rahmilah Bakri', Juli Amaliyah Nasucha ${ }^{2}$, Dwi Bhakti Indri M $^{3}$ \\ Institut Pesantren Kh. Abdul Chalim Pacet Mojokerto, Indonesia \\ Email: annisarahmilah@gmail.com¹ , amel.cemal.cemil53@gmail.com², indrifaith@gmail.com ${ }^{3}$}

\begin{tabular}{ll}
\hline & \\
\hline Kata & kunci: \\
Bermain & Peran, \\
Interaksi & Sosial, \\
Anak Usia Dini. \\
\hline
\end{tabular}

Keywords: Role Playing, Social Interaction, Kindergarten

\begin{abstract}
Guru memberi materi dengan metode ceramah, anak menerima materi dari penjelasan yang telah diberikan oleh guru, tugas yang diberikan berupa lembar kerja siswa dan buku kerja anak. Anak mencatat angka atau huruf/kata tanpa menciptakan konteks belajar terlebih dahulu. Dalam hal ini, pendidikan akademik atau intelektual anak berkembang dengan baik karena mendapat rangsangan atau stimuslus yang besar, sedangkan untuk yang non akademiknya kurang mendapat rangsangan atau stimulus atau seringkali disepelekan sehingga interaksi sosial sesama teman menjadi kurang. Penelitian memiliki rumusan masalah yaitu bagaimana kemampuan interaksi sosial anak yang diajarkan dengan metode bermain peran dan adakah pengaruh bermain peran terhadap interaksi sosial anak usia dini pada kelompok A di RA Thoriqul Ulum Sajen, Kecamatan Pacet Kabupaten Mojokerto. Jenis penelitian ini adalah pre eksperimental design dengan tipe one grup pretest-posttest dengan menggunakan teknik purposive sampling yaitu teknik pengambilan data dengan pertimbangan tertentu.Hasil penelitian ini menunjukkan adanya pengaruh yang signifikan antara metode bermain peran dengan interaksi sosial anak. Hal ini terlihat dari nilai rata -rata kemampuan interaksi sosial anak sebelum dan sesudah diberi perlakuan bermain peran yaitu 45.55 menjadi 60.95 . Hal ini juga dibuktikan dari hasil pengujian hipotesis dimana nilai sig. $<0,05$.
\end{abstract}

Abstrak
The teacher provides material with the lecture method, the child
receives material from the explanation given by the teacher, the
assignment given is in the form of student worksheets and children's
workbooks. The child records numbers or letters / words without
creating a learning context first. In this case, the academic or
intellectual education of children develops well because it gets a large
stimulus or stimulation, while for non-academics they get less
stimulation or stimulus or are often underestimated so that social
interactions among friends become less. The research has a problem
formulation, namely how the children's social interaction skills are
taught using the role-playing method and is there an effect of role
playing on early childhood social interaction in group A in RA

http://pasca.jurnalikhac.ac.id/index.php/tijie/index 
Thoriqul Ulum Sajen, Pacet District, Mojokerto Regency. This type of research is pre-experimental design with one group pretest posttest type using purposive sampling technique, namely data collection techniques with certain considerations. The results of this study indicate a significant influence between the role playing method and children's social interactions. This can be seen from the average value of children's social interaction skills before and after being given role playing treatment, namely 45.55 to 60.95 . This is also evidenced from the results of hypothesis testing where the sig. $<0.05$.

\section{PENDAHULUAN}

Menurut direktorat PAUD berinteraksi dengan orang lain dapat dilakukan oleh anak secara bertahap, karena seperti yang kita ketahui bahwa perkembangan anak dimulai dari egosentris individual yang dimana anak hanya memandang dari dirinya sendiri.Berdasarkan Permendikbud No 137 tahun 2017 tentang Standar Nasional Penyelenggaraan PAUD disebutkan bahwa anak usia dini dalam rentang waktu 5-6 tahun haruslah memiliki kemampuan dalam perkembangan sosial emosional yang mencakup kesadaran diri, rasa tanggung jawab untuk diri sendiri dan orang lain serta perilaku proporsional. ${ }^{1}$ Berinteraksi atau berhubungan dengan orang-orang yang ada disekitar mereka, merupakan proses belajar menyesuaikan diri dengan lingkungan dalam perkembangan sosialnya. Pada usia 5-6 tahun anak akan menunjukkan sikap toleransi sesama teman, mampu bekerja sama, mentaati aturan dan disiplin serta menunjukkan rasa empati, hal tersebut merupakan ciri dari perkembangan sosial anak. $^{2}$

Guru memberi materi dengan metode ceramah, anak menerima materi dari penjelasan yang telah diberikan oleh guru, tugas yang diberikan berupa lembar kerja siswa dan buku kerja anak. Anak mencatat angka atau huruf/kata tanpa menciptakan konteks belajar terlebih dahulu. Dalam hal ini, pendidikan akademik atau intelektual anak berkembang dengan baik karena mendapat rangsangan atau stimuslus yang besar, sedangkan untuk yang non akademiknya kurang mendapat rangsangan atau

1 Zumrotus Sholichah dan YatimRianto, "Penerapan Metode Bermain Peran Untuk Perkembangan Sosial Emosional Anak Usia 5-6 Tahun di Kelompok B UPT SPNF SKB Gresik". Volume 1. No.1 (Tahun 2012), 6.

2 Ulya Latifah, Anita Chandra Dewi Sagala, “Upaya Meningkattkan Interaksi Sosial Melalui Permainan Tradisional Jamuran Pada Anak Kelompok B TK Kuncup Sari Semarang Tahun Ajaran 2014/2015". Jurnal Penelitian PAUDIA, 114. 
stimulus atau seringkali disepelekan. Seperti yang telah dijelaskan oleh Dirjen PAUDNI bahwa: 1) proses pembelajaran lebih sering menggunakan calistung dan bermain sering kali diabaikan, 2) pendidikan guru masih sangat minim: pelatihan pendidik masih menjangkau 118.018 guru (29,32\%) dari 403.493 guru (diluar guru TPQ), 3) yang mengajar di PAUD belum sesuai dengan kualifikasi pendidik PAUD sekitar 15,72\%, 4) Jumlah lembaga PAUD rujukan /imbas mutu masih terbatas, yaitu baru sekitar 346 lembaga (0,3\%) dari 114.888 lembaga. 5) sebagaian besar kondisi prasarana dan sarana PAUD masih memperihatinkan. ${ }^{3}$ Secara kuantitas, guru PAUD jauh lebih sedikit dibandingkan dengan jumlah guru-guru pada strata pendidikan yang lain (SD, SMP, SMA).

Perkembangan PAUD akan menjadi semakin baik ketika guru atau pendidik memiliki kualifikasi atau kompetensi dibidangnya, begitu pula sebaliknya jika duru atau pendidik tidak memiliki kompetensi atau kualifikasi dibidang PAUD maka akan berdampak buruk bagi perkembangan PAUD. Pada saat anak memasuki pendidikan Sekolah Dasar anak akan di hadapkan pada pembelajaran calistung, hal tersebut memang sudah sesuai untuk anak yang masuk Sekolah Dasar berbeda dengan anak PAUD, mereka seharusnya diberikan kebebasan untuk bermain dan juga belajar untuk mengeskpresikan apa yang mereka ketahui dari permainan yang mereka lakukan, bukan dengan memberikan anak pembelajaran calistung yang seharusnya belum anak dapatkan. Seharusnya pada usia PAUD atau usia dini kemampuan dasar anak mulai dari kemampuan sosial-emosional, sains, dan seni, bahasa harus dikembangkan secara menyeluruh tidak hanya terfokus pada calistung (membaca-menulis-berhitung) ${ }^{4}$

Dalam sebuah proses pembelajaran dibutuhkan metode yang bervariatif dan aktif sehingga anak mendapatkan kesempatan untuk ikut secara andil dalam proses pembelajaran. Hendaknya metode pembelajaran yang diberikan tidak membuat anak merasa bosan, penggunaan metode pembelajaran yang kurang bervariatif dan aktif membuat suasana kelas menjadi pasif. Bermain membuat anak berinteraksi dengan anak yang lainnya. Memberi, menerima, ataupun menolak merupakan bentuk dari interaksi sosial yang diterima oleh anak secara tidak langsung melalui bermain. Hal

${ }^{3}$ Laelatul Istiqomah, "Tiga Pilar Kebijakan Pemerintah Dalam Pembinaan PAUD”, Golden Age, Vol. 1 No. 1 (April,2016) e-ISSN: 2502-3519, 62.

4 Bandi, "Manajemen Pendidikan Anak Usia Dini (PAUD) Untuk Meningkatkan Kualitas Pendidikan di TK Negeri Pringtali.... 231. 
tersebut perlahan-lahan akan mengurangi bentuk egoisentris anak dan mampu mengembangkan kemampuan sosialnya. Parten mengamati perkembangan bermain pada anak menggambarkan pula perkembangan sosial anak. ${ }^{5}$

Metode ceramah merupakan cara mengajar yang paling sering pakai oleh para pendidik. Penggunaan metode ceramah yang terus menerus dalam proses pembelajaran akan membuat anak merasa bosan, karena pada usia dini daya konsentrasi atau fokus anak masih sangat kecil dan masih sangat aktif bergerak. Penggunaan metode ceramah membuat anak tidak aktif bergerak, mereka hanya akan mendengarkan materi yang disampaikan oleh pendidik, sehingga kurangnya sosialisasi anak dengan teman-teman mereka. Agar anak dapat belajar secara aktif dan efektif maka diperlukan metode pembelajaran yang sesuai dengan dunia anak, pembelajaran yang mampu memacu bukan hanya dari segi perkembangan akademik tetapi juga memacu perkembangan non akademik seperti emosi dan keberanian anak untuk melakukan interaksi dengan teman yang lain.

Bermain peran adalah jenis permainan yang meliputi sandiwara, drama, dan bermain pura-pura. Permainan ini baik untuk menumbuhkan penguasaan berbahasa anak, komunikasi, dan paham akan peran-peran dalam masyarakat. Biasanya di TK ataupun lembaga pendidikan anak lainnya memiliki pojok keluarga atau pojok bermain peran (socio-dramatic play center). Semisal anak melakukan permain bermain peran seperti seorang pembeli dan penjual. Berdasarkan permainan itu anak-anak belajar untuk berintraksi dengan orang lain secara tidak langsung anak sudah berinteraksi dengan orang lain. ${ }^{6}$

Dari hasil study pendahuluan yang dilakukan di RA Thoriqul Ulum tentang bermain peran, guru menggunakan beberapa metode pembelajaran dalam proses mengajar yaitu: 1) metode ceramah, 2) metode tanya jawab/diskusi, 3) metode demonstrasi serta 4) metode berkelompok namun yang guru lebih sering menggunakan metode ceramah saat memberikan materi pembelajaran, sehingga interaksi yang terjadi hanya interaksi satu arah yaitu hanya guru dan peserta didik, tidak ada interaksi yang terjadi antara peserta didik saat proses pembelajaran.

Peserta didik hanya akan berbicara ketika ada arahan dari guru. Pembelajaran yang diberikan juga masih mengutamakan calistung. Pemberian materi calistung

5 Slamet Suyanto, Dasar-dasar Pendidikan Anak Usia Dini...,.,121.

6 Slamet Suyanto, Dasar-dasar Pendidikan Anak Usia Dini...,.,126. 
merupakan tuntutan masyarakat setempat yang menyekolahkan anaknya di RA Thoriqul Ulum. Peserta didik dituntut agar bisa calistung pada saat keluar dari sekolah sehingga ketika memasuki sekolah dasar anak sudah memiliki kemampuan calistung. Selain itu anak diajak menggambar, mewarnai, menempel dan menggunting, kegiatan pembelajaran dilakukan secara indvidual. Guru jarang memberikan pembelajaran kepada peserta didik secara berkelompok dan juga media yang digunakan masih kurang bervariatif sehingga interaksi sosial anak masih belum berkembang secara optimal.

Dari permasalahan yang telah dikemukakan di atas, pembelajaran menggunakan metode bermain peran dilakukan oleh peneliti untuk mengembangkan interaksi sosial anak. Metode ini juga bertujuan untuk membangun pola-pola hubungan antara pemeran satu sama lain sehingga membentuk perasaan-perasaan yang baru. Maka dari itu, peneliti ingin mempergunakan metode bermain peran yang dimana bermain peran yang digunakan yaitu bermain peran sederhana, untuk mengetahui pengaruh bermain peran terhadap interaksi sosial anak usia dini di kelas A RA Thoriqul Ulum Sajen.

\section{LANDASAN TEORI}

\section{Bermain Peran}

Kegiatan bermain adalah kegiatan yang didalamnya anak belajar dan tahu berbagai hal seperti mengerti suatu aturan, sosialisasi, menempatkan diri pada lingkungan, mengelolah emosi, kerjasama, serta toleransi dan sportif dalam bermain. Selain itu, keterampilan motorik, kecerdasan intelektual, spiritual, dan bahasa anak dapat berkembang melalui bermain. Kegiatan pembelajaran yang sangat penting bagi anak yaitu bermain, karena dengan bermain anak memperoleh banyak hal, selain itu bermain juga merupakan dunia anak. ${ }^{7}$

Jika menginginkan agar anak dapat menjadi sehat dan bahagia, maka harus diberi kesempatan untuk bermain dan menggerakkan tubuhnya. Anak yang selalu dipaksa untuk melakukan suatu pekerjaan dan tidak dibiarkan berolahraga, akhirnya anak akan menjadi anak yang kurang pandai. Oleh karena itu, dalam tahun pertama atau tahapan awal kehidupannya, anak harus memiliki kebebasan penuh dalam bermain dan berolahraga. Pada masa ini, orang tua maupun pendidik memberikan

${ }^{7}$ Mulyasa, Manajemen PAUD,... 66. 
keleluasaan kepada anak mereka melakukan aktivitas dan kegiatan. Rasulullah bersabda, bahwa jika ketika kita memiliki seorang anak kecil, maka kita juga harus bertingkah layaknya seorang anak kecil, atau dengan kata lain mengikuti apa yang dilakukan oleh anak tersebut.

Bermain sambil belajar merupakan suatu proses pembelajaran bagi anak yang mendominasi kepada permainannya secara betahap anak-anak mulai belajar sambil bermain yang dimana belajarnya lebih dominan sesuai dengan tahapan perkembangan anak. Dengan demikian, kematangan dan tahap perkembangan peserta didik, harus terus diperhatikan dalam bermain, dan juga alat bermain atau alat bantu yang digunakan saat bermain. Dalam proses belajar orang tua ataupun guru sering kali membatasi anak untuk bermain, padahal ketika bermain anak sudah dalam proses belajar yang dimana hal tersebut sangat penting untuk anak. Akibatnya, nasihatnasihat yang akan diberikan oleh orang tua sukar diterima anak karena lebih banyak hal yang disukai orang tua, tetapi tidak disukai anak. Pemberian pendidikan kepada anak usia dini harus sesuai dengan tingkat perkembangan mereka, karena jika pendidikan yang diberikan tidak sesuai maka akan berpengaruh juga kepada anak, maka dari itu seorang guru maupun orang tua harus paham tentang perkembangan anak usia dini agar tidak terjadi mispersepsi. ${ }^{8}$

Bermain pura-pura, khayalan, fantasi, make believe, atau simbolik merupakan nama lain dari bermain peran. Perilaku anak dibuktikan melalui bermain peran menurut padangan Piaget, awal bermain peran dapat menjadi bukti perilaku anak. Melalui bermain peran anak akan mengingat peran yang dimainkannya yang menurutnya menyenangkan ataupun yang membuat anak menjadi sedih, secara tidak langsung anak akan mengulang-ulang peran yang menyenangkan dan menjadikan sebuah pelajaran peran sedih yang diterima olehnya. Anak yang terlibat atau melakukan bermain peran untuk mencapai tahapan yang lebih tinggi disebut juga sebagai collective symbolism hal ini dikemukakan oleh Piaget. ${ }^{9}$

Bermain peran dapat digunakan untuk mendidik anak untuk belajar tanggung jawab pada kehidupan sosial dalam kelompok kecil. Dalam mengambil sebuah

8 Mansru, Pendidikan Anak Usia Dini Dalam Islam,....167-168.

9 Vera Ayuningtiyas, "Metode Bermain Peran (Role Playing) dalam Upaya Menumbuhkembangkan Keteramapilan Berbicara Bahasa Indonesia pada Anaka Usia Dini di TK Bhayangkari 17 Cimahi", Jurnal Empowerment, Vol.2, No.2, (September, 2013) ISSN No. 2252-47738,50-52. 
keputusan, mempelajari tingkah laku manusia, mngungkapkan perasaan danmengetahui tingkah laku seseorang anak akan mendapatkan hal tersebut dalam metode bermain peran, maka hal ini sangat cocok untuk anak. Dengan bermain peran anak mulai berfikir secara simbolik, atau dengan kata lain anak mulai mampu mengetahui bentuk-bentuk dari sebuah perasaan, mampu memahami apa yang dirasakan oleh orang lain ataupun dirinya sendiri.

Pendapat Moeslichatoen tentang bermain peran adalah anak-anak bermain dengan cara berkhayal atau bertingkah laku menjadi orang lain, atau orang tertentu ataupun binatang atau hal lainya yang dalam dunia nyata tidak dilakukan. Sedangkan Vygotsky mengatakan bahwa bermain peran adalah bermain berpura-pura, yang memiliki simbol, dan juga melibatkan imajinasi yang memiliki fungsi penting dalam perkembangan emosinal, kognisi serta sosial anak usia 3-6 tahun. Bermain peran akan membantu pengembangan aspek emosional, sosial, mental, intelektual, moral agama dan fisik anak, karena dalam bermain peran, selain anak di tuntut untuk mampu bertutur secara verbal, anak-anak pun di tuntut untuk mampu mengomunikasikan gagasannya melalui bahasa tubuhnya. ${ }^{10}$

\section{Interaksi Sosial}

Salah satu faktor yang mempengaruhi perkembangan sosial anak yaitu kemampuan mengambil peran dalam kehidupan sosial. Mereka sadar akan perasaan, pikiran, dan sikap orang lain. Citra diri negatif atau positif anak dipengaruhi dari apakah anak itu bisa bergaul atau tidak. Sehingga ketika anak berada pada lingkungan sosial anak memiliki kemampuan untuk menempatkan diri pada lingkungan tempat tinggalnya, anak akan diterima pada lingkungan tempat tinggalnya, perlakuan yang baik selama melakukan aktivitas sosial akan menjadi modal dasar bagi anak untuk kehidupan sosialnya yang akan datang. ${ }^{11}$

Perilaku-perilaku yang mencakup keterampilan sosial menurut Janice J Beaty adalah: a) empati yaitu anak-anak mencurahkan rasa harunya dengan peduli dengan teman yang terkena musibah dengan merasakan apa yang dirasakan oleh orang lain ; b) kemurahan hati atau kedermawanan yaitu anak-anak mampu memberi dan

${ }^{10}$ Dinaar Nur Inten, “ Pengembangan Keterampilan Berkomunikasi Anak Usia Dini Melalui Metode Bermain Peran", MediaTor, Vol.10, No.1, 113.

11 Ulya Latifah dan Anita Chandra Dewi Sagala, “Upaya Meningkatkan Interaksi Sosial Melalui Permainan Tradisional Jamuran Pada Anak Kelompok B TK Kuncup Sari Semarang Tahun Pelajaran 2014/2015",...114. 
membagikan barang yang dimilikinya; c) kerjasama yaitu anak bersama-sama dalam mengerjakan sesuatu tanpa adanya pertengkaran atau perkelahian dan melakukan permainan secara bergiliran; dan d) memberi bantuan yaitu anak menolong atau memberikan bantuan kepada teman yang sedang membutuhkan. ${ }^{12}$ Perilaku tidak sosial menurut Elizabeth. B. Hurlock yaitu perilaku yang menunjukkan: 1) Negativisme, adalah perilaku melawan atau tidak menuruti perintah yang diberikan yang sefatnya seperti sebuah kemarahan, 2) agresi, adalah sebuah tindakan yang memusuhi, 3) pertengkaran, adalah biasanya dilakukan karena sebuah perselisihan paham yang karena sesuatu hal, 4) mengejek dan menggretak, mengejek menjelekjelekkan orang lain secara lisan, sedangkan menggretak adalah serangan fisik kepada seseorang karena ketidak sukaan kepada korban, 5) perilaku yang sok kuasa, perilaku seseorang yang ingin menjadi "bos" atau "majikan" dengan cara memerintah atau menyuruh, 6) egosentris, semua anak pada dasarnya bersifat egosentris yaitu anak hanya memandang dirinya sendiri tanpa menghiraukan orang lain. Hal tersebut jika dibiarkan terus menerus maka akan menetap pada diri anak sampai ketika ia dewasa, 7) prasangka, anak menyadari bahwa diri mereka lebih dari temannya, sehingga anak mudah untuk merendahkan atau meremehkan orang lain, 8) antagonisme jenis kelamin, disaat anak laki-laki menghindar untuk bermain dengan anak perempuan, atau anak laki-laki dilarang oleh keluarganya untuk bermain dengan anak perempuan.

Pada usia sekiar 7 tahun Piaget menyebutkan bahwa anak pada usia tersebut sudah mampu untuk bekerjasama dengan orang lain, hal itu dikarenakan anak sudah tidak lagi mencampur baurkan sudut pandangnya sendiri dengan sudut pandang orang lain. Penyesuaian diri dengan orang lain telah dilakukan untuk memfokuskan pada hubungan antar pola perilaku atau status anak dengan teman sebayanya hal tersebut dikemukakan oleh Tarsidi.

Secara umum interaksi diartikan sebagai hubungan yang saling bereaksi antara individu dengan individu yang lain ataupun lebih. Dan untuk sosial berhubungan dengan kehidupan bermasyarakat. Olehnya itu, secara keseluruhan interaksi sosial

12 Yulia Siska,"Penerapan Metode Bermain Peran (Role Playing) dalam meningkatkan keterampilan sosial dan keterampilan Berbicara Anak Usia Dini". Edisi khusus, No.2 (Agustus 2011),ISSN 1412-565X, 33. 
diartikan sebagai komunikasi yang terjadi dalam sebuah kelompok yang berkesinambungan dalam melakukan tindakan sosial ataupun tidak. ${ }^{13}$

Untuk menumbuhkan komunikasi yang harmonis pada lingkungan maka dilakukanlah interaksi sosial yang meliputi keterampilan berkomunikasi dengan orang lain. Dalam lingkungan sosial tindakan seorang individu yang mempengaruhi individu lainnya merupakan suatu tindakan interaksi sosial hal ini di kemukakan oleh Max Weber dalam Witarsa.

Dalam sebuah hubungan dengan individu atau kelompok maka diperlukan sebuah komunikasi atau interaksi untuk mempengaruhi individu atau kelompok tersebut hal ini dikemukakan oleh Bonner dalam Ahmadi. Interaksi tersebut dapat terjadi dengan individu-individu yang lain di dalam kelompok. ${ }^{14}$

Kerjasama, pertikaian dan juga persaingan merupakan bentuk dari suatu interaksi yang dilakukan oleh individu dengan individu maupun kelompok dengan kelompok, hal ini juga dikemukakan oleh Basrowi. ${ }^{15}$ Vygotsky percaya bahwa interaksi sosial membawa anak-anak ke nilai-nilai dan keyakinan yang mencerminkan interaksi itu dan interaksi masyarakat atau budaya yang mereka wakili. ${ }^{16}$

Maka dapat ditarik kesimpulan bahwa interaksi sosial adalah hubungan atau komunikasi yang dilakukan oleh dua orang atau lebih yang saling mempengaruhi satu sama lain dengan tujuan tertentu. ${ }^{17}$

Dalam sebuah hubungan dengan individu atau kelompok maka diperlukan sebuah komunikasi atau interaksi untuk mempengaruhi individu atau kelompok tersebut hal ini dikemukakan oleh Bonner dalam Ahmadi. Interaksi tersebut dapat terjadi dengan individu-individu yang lain di dalam kelompok. ${ }^{18}$ Maka dapat ditarik kesimpulan bahwa interaksi sosial adalah hubungan atau komunikasi yang dilakukan

\footnotetext{
${ }^{13}$ Robbiyah, Diyan Ekasari dan Ramdhan Witarsa, “Pengaruh Pola Asih Terhadap Kecerdasan Sosial Anak Usia Dini di TK Kenanga Kabupaten Bandng Barat", Jurnal Obsesi, Vol. 2, No.1 (2018), 81.

14 Ulya Latifah dan Anita Chandra Dewi Sagala, “Upaya Meningkatkan Interaksi Sosial Melalui Permainan Tradisional Jamuran Pada Anak Kelompok B TK Kuncup Sari Semarang Tahun Pelajaran 2014/2015",... 117.

15 Ibid., 117.

16 Pat Beckley, Belajar Pada Anak Usia Dini, (Jakarta: Penerbit Indeks Jakarta, 2018), 202.

17 Pat Beckley, Belajar Pada Anak Usia Dini... 81.

18 Ulya Latifah dan Anita Chandra Dewi Sagala, “Upaya Meningkatkan Interaksi Sosial Melalui Permainan Tradisional Jamuran Pada Anak Kelompok B TK Kuncup Sari Semarang Tahun Pelajaran 2014/2015",... 117.
} 
oleh dua orang atau lebih yang saling mempengaruhi satu sama lain dengan tujuan tertentu. ${ }^{19}$ Interaksi sosial dapat dibedakan menjadi beberapa jenis, yaitu:

Interaksi verbal: Penggunaan alat-alat artikulasi atau pembicara dalam suatu interaksi adalah bentuk dari interaksi verbal yang pada saat proses terjadinya yaitu berbentuk saling bertukar percakapan satu sama lain. Pada saat bermain interaksi verbal anak dapat terlihat. Hal ini sesuai dengan pendapat sejalan Pramudya dan Soefandi bahwa peran sangat cocok dalam mengembangkan imajinasi anak dalam bercakap-cakap.

Interaksi fisik: Penggunaan bahasa tubuh, mimik wajah, ataupun kontak mata merupakan interaksi fisik yang melibatkan anggota tubuh mereka dalam berkomunikasi atau berinteraksi.

Interaksi emosional: Saat mengeluarkan air mata, atau mencurahkan isi hati mereka ketika berkomunikasi atau berhubungan merupakan interaksi emosional yang melibatkan perasaan mereka. Pada saat bermain kemampuan interaksi emosional anak dapat terlihat. Wardani mengemukakan bahwa pada saat bermain seseorang mampu mengekpresikan dirinya atau meluapkan segala bentuk emosi yang ada dalam dirinya entah itu rasa marah, senang ataupun sedih.

\section{Anak Usia Dini}

Anak usia dini adalah anak yang berusia 0-6 tahun yang memiliki masa golden age atau masa keemasan dimana anak sangat peka terhadap rangsangan yang ada disekitarnya karena pada masa tersebut fungsi-fungsi dan juga psikis anak mulai berkembang dengan baik. Pada masa peka anak atau masa golden age merupakan masa dimana anak sangat baik ketika diberi pembelajaran dasar untuk mengembangkan kemampuan fisik, kognitif, bahasa, seni, sosial emosional, spiritual, konsep diri, disiplin diri, dan kemandirian. Pada usia dini proses perkembangan dan pertumbuhan anak berjalan dengan sangat cepat, bahkan dikatakan sebagai lompatan perkembangan. Pada usia dini anak memiliki kecerdasan yang luar biasa dibandingkan dengan usia-usia selanjutnya. ${ }^{20}$ Dalam Undang-Undang Republik Indonesia Nomor 20 Tahun 2003 tentang sistem Pendidikan Nasional pada Pasal 1 ayat

19 Pat Beckley, Belajar Pada Anak Usia Dini... 81.

${ }^{20}$ Mulyasa, Manajemen PAUD,...16. 
14 yang mengemukakan pendidikan anak usia dini merupakan pendidikan yang ditujukan untuk, anak sejak lahir sampai usia 6 tahun. ${ }^{21}$

Pada saat anak masih usia dini, disitulah waktu yang tepat untuk memberikan nilai-nilai dasar nasionalisme, dan sosial yang berguna untuk kehidupan anak selanjutnya. Secara umum anak usia dini dibagi menjadi beberapa kelompok usia (0-1 tahun), (2-3 tahun), dan (4-6 tahun); dengan karakteristik masing-masing. Perkembangan dan pertumbuhan adalah suatu proses perubahan yang terjadi dalam kehidupan manusia yang berlangsung secara berkelanjutan sejak masa konsepsi sampai akhir hayat. Perubahan-perubahan yang dialami oleh setiap individu mulai dari perubahan bentuk tubuh sampai dengan pola pikir hal tersebut menunjukkan bahwa seorang individu mengalami tingkat kematangan atau kedewasaan yang berlangsung secara berkelanjutan, bertahap dan juga sistematis. Perkembangan anak usia dini pada usia 4-6 tahun yaitu berkembangnya fisik dan motorik, kognitif, sosial, emosional serta bahasa anak. ${ }^{22}$

Anak usia dini (3-6 tahun) memiliki perbedaan dengan anak usia bayi, dan memiliki ciri yang sangat berbeda pula. Perbedaanya terletak pada penampilan, proporsi tubuh, berat dan panjang badan, serta keterampilan yang mereka miliki.23 Para ahli pendidikan sepakat bahwa periode keemasan atau masa golden age hanya terjadi satu kali sepanjang masa kehidupan manusia. Hal tersebut memperlihatkan bahwa betapa meruginya suatu bangsa, masyarakat dan keluarga, jika melewatkan masa-masa penting yang berlangsung pada anak usia dini. ${ }^{24}$

Mengacu pada teori Piaget, anak usia dini dapat dikatakan sebagai usia yang belum dapat dituntut untuk berpikir secara logis, yang ditandai dengan pemikiran sebagai berikut: 1) anak belum mampu memahami sesuatu yang bersifat abstrak, 2) realisme, anak lebih cenderung untuk mendapatkan sesuatu yang nyata, 3) egoisentris, anak hanya peduli kepada dirinya sendiri tanpa memikirkan orang lain, 4) anak masih berfikir secara sederhana dan masih sulit untu menerima hal-hal yang bersifat majemuk, 5) animisme, yaitu kecenderungan untuk berfikir bahwa semua objek yang ada di lingkungannya memiliki kualitas kemanusiaan sebagaimana yang dimiliki anak,

${ }^{21}$ Putri Hana Pebriana, “Analisis Penggunaan Gadget Terhadap Kemampuan Interaksi Sosial Pada Anak Usia Dini", ,...3.

${ }^{22}$ Novan Ardy Wiyani dan Barnawi, Format PAUD, ...84.

${ }^{23}$ Novan Ardy Wiyani dan Barnawi, Format PAUD..., 85.

24 Novan Ardy Wiyani dan Barnawi, Format PAUD..., 34. 
6) sentrasi, anak lebih memfokuskan dirinya kepada satu hal dari suatu situasi, 7) anak memiliki imajinasi yang sangat tinggi dan banyak akal untuk melakukan berbagai hal. ${ }^{25}$

Anak merupakan bagian dari keluarga yang perlu diberikan kepadanya normanorma,nilai-nilai agama, pendidikan, memberikan kesempatan kepada pada anak untuk belajar tingkah laku dan motif-motif yang penting untuk berkembang dan berfungsi baik dalam kehidupan bersama. Dalam Alquran, anak disebut juga sebagai berita baik, hiburan pada pandangan mata, dan perhiasan hidup. Anak merupakan amanat dari Allah SWT, yang harus dijaga, di didik serta diberi bekal hidup agar menjadi seseorang yang berguna dan dewasa dari segi fisik maupun mental. Orang tua dan masyarakat berkewajiban memberikan perlindungan. ${ }^{26}$

Lingkungan hidup anak, sangat mempengaruhi perkembangan kepribadian anak, faktor lingkungan hidup yang sangat mempengaruhi perkembangan kepribadian anak yaitu dari lingkungan keluarga yang meliputi orang tua, kakak, adik ataupun sanak saudara lainnya. Dari lingkungan keluarga anak belajar berbahasa, mengumpulkan pengertian-pengertian dan menggunakan nilai-nilai kebudayaan yang berlaku. Anak merupakan kebahagiaan bagi orang tuanya, penerus bangsa yang akan mengharumkan nama bangsa kelak ketika ia dewasa, olehnya itu anak membutuhkan perhatian khusus serta pendidikan yang baik agar kelak menjadi anak yang berguna bagi nusa dan bangsa.

Sesungguhnya kecintaan kepada harta benda dan anak-anak adalah cobaan dan ujian, sebab sering kali hal itu, menyebabkan perbuatan dosa dan pelanggaran terhadap apa-apa yang terlarang. Anak pada prinsip dasar memiliki potensi kebaikan, ketika dilahirkan oleh ibunya, oleh karena itu bila potensi ini dikembangkan maka anak tumbuh dan berkembang dengan nilai-nilai yang baik. Oleh karena itu anak harus dibimbing ke arah kesalehan, sehingga akan membawa manfaat ketika sudah baligh dan dewasa, sebaliknya bila potensi dasar anak yang baik itu, tidak dibina, diarahkan, dikembangkan, karena dapat saja anak itu menjadi musuh dan sudah pasti tidak berguna. ${ }^{27}$

${ }^{25}$ Novan Ardy Wiyani dan Barnawi, Format PAUD..., 36.

26 Ayuhan, Konsep Pendidikan Anak Salih Dalam Perspektif Islam..., 42.

27 Ayuhan, Konsep Pendidikan Anak Salih Dalam Perspektif Islam..., 46. 


\section{METODE PENELITIAN}

Pada penelitiaan ini peneliti menggunakan metode penelitian eksperimen. Penggunaan metode eksperimen dilakukan untuk mencari adakah pengaruh yang didapatkan ketika melakukan suatu tindakan pada suatu objek dan dalam kondisi yang terkendalikan. ${ }^{28}$ Penelitian ini menggunakan metode pre-experimental design tipe one group pretest-posttest (tes awal-tes kelompok tunggal). Arikunto mengemukakan, bahwa tipe one group pretest-posttes design adalah kegiatan penelitian yang diberi tes awal (pretest) sebelum diberikan perlakuan, setelah diberikan perlakuan barulah memberikan tes akhir (posttest). ${ }^{29}$

Penggunaan desain ini disesuaikan dengan tujuan yang hendak dicapai, yaitu untuk mengetahui interaksi sosial anak usia dini sebelum dan sesudah diberikan perlakuan. Desain ini dapat digambarkan sebagai berikut:

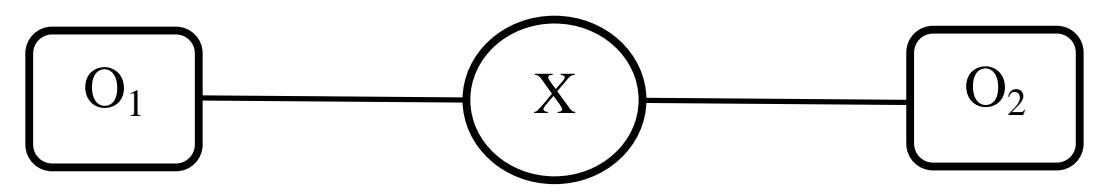

Keterangan:

$\mathrm{O}_{1}$ : Pretest/Observasi diberikan sebelum menggunakan metode Bermain Peran.

$X$ : Pemberian atau penggunaa metode Bermain Peran.

$\mathrm{O}_{2}$ : Posttest/Perlakuan diberikan setelah menggunakan metode Bermain Peran.

Adapun lokasi penelitian yaitu di RA Thoriqul Ulum Sajen, dengan jumlah populasi sebanyak 53 anak dan sampel sebanyak 20 anak. Dengan analis data yaitu menggunakan analisis data deskriptif, uji normalitas dan uji paired sampel t-test. Adapun teknik pengumpulan datanya yaitu :

\section{Metode Observasi}

Metode observasi adalah cara yang digunakan dalam memperoleh data dengan cara mengamati secara langsung objek yang akan diteliti. Metode observasi dapat digunakan untuk mengamati tingkah laku manusia, gejala- gejala alam yang terjadi. Obesrvasi ini dilakukan peneliti sebelum memberikan perlakuan, saat diberi perlakuan dan sesudah diberi perlakuan dengan menggunakan metode bermain peran untuk mengetahui interaksi sosial anak di RA Thoriqul Ulum Sajen.

28 Ibid., 107.

${ }^{29}$ Arikunto, Prosedur Peneltian: Suatu Pendekatan Praktek, (Jakarta: Rineka Cipta, 2010), 124. 


\section{Metode Dokumentasi}

Metode dokumentasi adalah pengambilan data langsung dari tempat penelitian yang meliputi buku-buku yang relevan, peraturan-peraturan, laporan kegiatan, fotofoto, dan data yang relevan dengan penelitian.

\section{Wawancara (Interview)}

Wawancara adalah suatu bentuk komunikasi yang dilakukan untuk mendapatkan sebuah informasi. ${ }^{30}$ Pengumpulan data dengan wawancara yaitu dengan memberikan sebuah pertanyaan kepada responden dan hasil wawancara responden dicatat atau direkam. Wawancara dapat dilakukan secara langsung ataupun tidak langsung tergandung dari kondisi atau waktu yang diberikan oleh responden, jika responden bisa untuk wawancara langsung maka pengumpulan data dapat dilakukan secara langsung, tetapi jika tidak maka dapat dilakukan secara tidak langsung yaitu melalui media komunikasi lainnya yang dapat menghubungkan antara pewawancara dan responden.

Data yang didapatkan dari hasil wawancara dikumpulkan sebagai data penunjang atau pendukung informasi dalam penelitian. Wawancara yang digunakan dalam penelitian ini adalah bebas tetapi tetap terstruktur artinya peneliti memberikan pertanyaan kepada responden tidak terpaut pada kerangka wawancara yang telah dibuat, peneliti bebas menanyakan apa saja kepada responden. ${ }^{31}$

Wawancara ini dilakukan untuk mencari data tentang bagaimana Pengaruh Bermain Peran Terhadap Interaksi Sosial Anak Usia Dini Kelas A RA Thoriqul Ulum Sajen.

\section{Instrumen Pengumpulan Data}

Instrumen dalam sebuah penelitian adalah alat yang digunakan untuk mengumpulkan data sesuai dengan objek yang akan diteliti. Dalam penelitain ini, peneliti menggunakan dua instrumen yaitu instrumen untuk metode bermain peran dan instrumen untuk interaksi sosial anak kelas A di RA Thoriqul Ulum Sajen.

\section{Analisis data}

\section{Analisis Deskriptif}

Analisis deskriptif adalah salah satu metode yang digunakan oleh peneliti dalam menganalisis data. Menurut Sugiyono, statistik deskriptif adalah "statistik yang

30 S.Nasution,Metode Reserch (Penelitian Ilmiah), (Jakarta: Bumi Aksara, 2006), 113.

31 Suharsini Arikunto,Prosedur Penelitian Suatu Pendekatan Praktis, (Jakarta : Rineka Cipta, 1991), 199. 
digunakan untuk menganalisa data dengan cara mendeskripsikan atau menggambarkan data yang telah terkumpul sebagaimana adanya tanpa bermaksud membuat kesimpulan yang berlaku untuk umum atau generalisasi". ${ }^{32}$

Analisis deskriptif dilakukan untuk mengetahui nilai variabel $X$ dan varibel $Y$ dan juga bagaimana pengaruh bermain peran terhadap interaksi sosial anak, dengan rumus sebagai berikut:

a. Rata-rata hitung (Mean)

Mean meupakan teknik penjelasan kelompok yang didasarkan atas nilai rata-rata dari kelompok tersebut. Rata-rata hitung (mean) dapat dirumuskan sebagai berikut:

$$
\bar{X}=\frac{\sum X_{i}}{n}
$$

Keterangan:

$\bar{X}=$ Mean (Rata-rata)

$\Sigma X_{i}=$ Jumlah nilai $X$ ke i sampai $\mathrm{n}$

$\mathrm{n} \quad=$ Jumlah sampel atau banyak data

b. Standar Deviasi

Standar deviasi atau simpangan baku dari data yang telah disusun dalam tabel distribusi frekuensi atau data bergolong dapat dihitung dengan rumus sebagai berikut:

$\mathrm{S}=\frac{\sqrt{\sum f i(X i-X)^{2}}}{(n-1)}$

Keterangan:

$\mathrm{S}=$ Simpang baku

$X_{i}=$ Nilai $X$ ke i sampai $n$

$X=$ Rata-rata nilai

$\mathrm{n}=$ Jumlah sampel

\section{Uji normalitas}

Uji normalitas merupakan pengujian terhadap data yang akan dianalis untuk mengetahui apakah data tersebut berdistribusi normal ataut tidak. Pengujian dilakukan tergantung variabel yang akan diolah. Uji normalitas sebaran data menggunakan Kolmogorov-Smirnov Test dengan bantuan SPSS 23.

Menurut metode Kolmogorov-Smirnov Test, kriteria pengujian adalah sebagai berikut: 1) Jika signifikan di bawah 0,05 berarti data yang akan diuji mempunyai perbedaan yang signifikan dengan data normal baku, berarti data tersebut tidak normal. 2) Jika signifikan di atas 0,05 maka berarti tidak terdapat perbedaan yang

32 Suharmi Arikunto, Dasar - dasar Evaluasi Pendidikan...206. 
signifikan antara data yang akan diuji dengan data normal baku, berarti data tersebut normal.

\section{Paired Sampel T-test}

Uji paired sampel T-test adalah pengujian yang dilakukan untuk menguji hipotesis yang telah dibuat, adapun ciri-ciri nya yaitu ojek penelitian diberikan dua perlakuan yang berbeda. Walaupun menggunakan individu yang sama, peneliti memperoleh 2 macam data sampel, yaitu data dari perlakuan pertama dan data dari perlakuan kedua. ${ }^{33}$ Rumus Paired Sampel T-test:

$$
\begin{aligned}
& t_{\text {hit }}=\frac{\bar{D}}{\frac{S D}{\sqrt{n}}} \\
& \text { Ingat: } \\
& \text { (var) }=s^{2}=\frac{1}{n-1} \sum\left(x_{i}-\bar{x}\right)^{2} \\
& S D=\sqrt{\text { var }} \\
& \text { Keterangan: } \\
& \mathrm{t}=\text { nilai } \mathrm{t} \text { hitung } \\
& \bar{D}=\text { rata-rata selisih pengukuran } 1 \text { dan } 2 \\
& S D=\text { standar deviasi selisih pengukuran } 1 \text { dan } 2 \\
& \mathrm{n}=\text { jumlah sampel } 34
\end{aligned}
$$

\section{HASIL \& PEMBAHASAN}

Secara umum siswa kelas A1 setelah diberi perlakuan mengalami peningkatan. Skor terendah siswa kelas A1 saat pretest adalah 30, setelah diberi perlakuan skor posttest menjadi 58. Skor tertinggi pretest adalah 54, setelah diberi perlakuan skor posttest tertinggi adalah 66. Berdasarkan data hasil penelitian diketahui bahwa nilai siswa mengalami peningkatan.

\section{Rekapitulasi pretest dan posttest Peningkatan Interaksi Sosial Anak kelas A1 dengan Penerapan Bermain Peran Grafik}




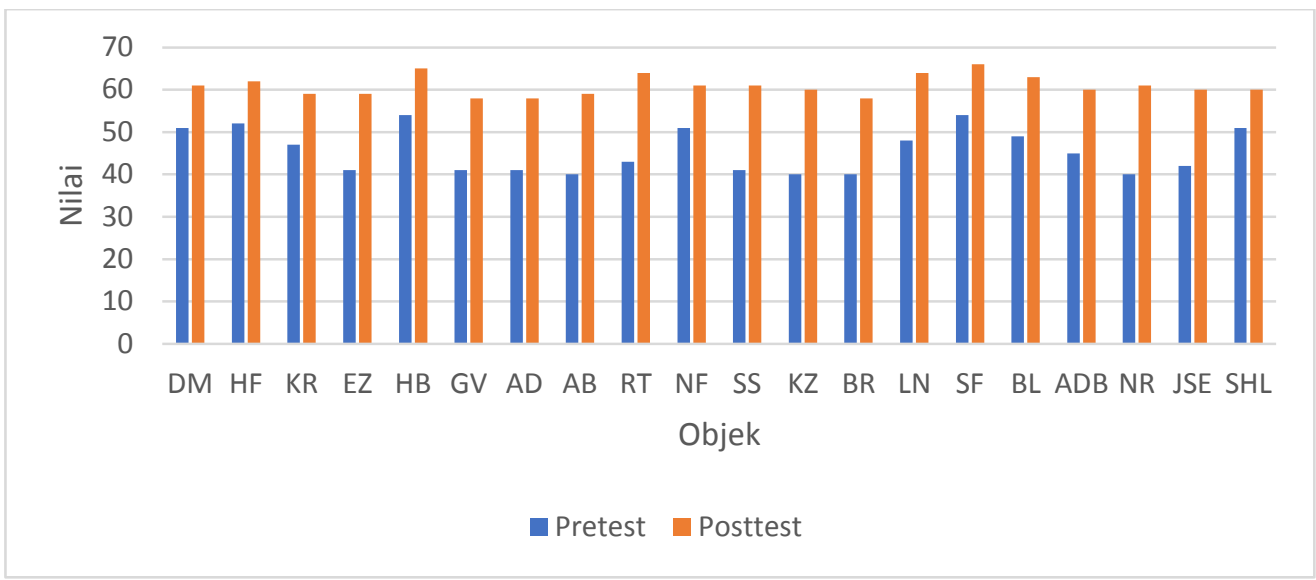

Sumber: Olah data Penelitian

Grafik di atas menampilkan perbedaan antara sebelum dan sesudah diberi perlakuan atau treatment berupa bermain peran untuk meningkatkan interaksi sosial anak kelas A1 RA Thoriqul Ulum. Grafik di atas menunjukkan adanya pengaruh antara sebelum dan setelah diberikan perlakuan.

\section{Analisis Deskriptif}

\begin{tabular}{|c|c|c|c|c|c|}
\hline \multicolumn{6}{|c|}{ Tabel } \\
\hline \multicolumn{6}{|c|}{ Descriptive Statistics } \\
\hline & $\mathrm{N}$ & Minim & Maximu & Mean & Std. \\
\hline & & $\mathrm{um}$ & $\mathrm{m}$ & & Deviation \\
\hline Pre-test & 20 & 40 & 54 & 45.55 & 5.226 \\
\hline Post-test & 20 & 58 & 66 & 60.95 & 2.373 \\
\hline Valid N (listwise) & 20 & & & & \\
\hline
\end{tabular}

Sumber: Olah data Penelitian

Analisis deskriptif dilakukan untuk menguraikan kecenderungan hasil kecakapan responden dari pembelajaran bermain peran terhadap interaksi sosial anak usia dini. Rangkuman statistik deskriptif pada saat pretest dilakukan terhadap interaksi sosial anak menunjukkan nilai minimum dan maksimum sebesar antara 40 dan 54 dengan mean sebesar 45.55 nilai ini menunjukkan bahwa skor hasil pretest memiliki nilai di atas rata-rata, dan nilai standar deviasi sebesar 5.226 ini berarti data yang diperoleh menyebar atau tidak terpusat pada satu nilai tertentu. Sementara hasil yang diperoleh dari posttest yaitu dengan nilai minimum dan maksimum sebesar antara 58 dan 66 dengan mean 60.95 dan standar deviasi 2.373 ini berarti nilai dari data yang 
diperoleh mengalami peningkatan, ini berarti data yang diperoleh juga menyebar atau tidak terpusat pada nilai tertentu.

\section{Uji Normalitas}

Uji normalitas digunakan untuk mengetahui apakah distribusi data tersebut normal atau tidak. Pada penelitian ini uji normalitas dilakukan pada kedua variabel penelitian, yaitu bermain peran dan interaksi sosial anak kelas A1 RA Thoriqul Ulum. Uji normalitas dilakukan dengan bantuan program SPSS menggunakan taraf signifikan $5 \%$, tabel berdistribusi normal jika signifikansi $(\alpha)$ misalkan pada $\alpha=5 \%$ atau 0,05 .

\section{Tabel}

Hasil Uji Normalitas

One-Sample Kolmogorv-Smirnov Test

\begin{tabular}{lll}
\hline & & \multicolumn{1}{c}{ Unstandardized Residual } \\
$\mathrm{N}$ & & 20 \\
Normal & Mean & .0000000 \\
Parametersa,b & Std. Deviation & 3.94444829 \\
Most Extreme & Absolute & .110 \\
Differences & Positive & .085 \\
& Negative & -.110 \\
Test Statistic & .110 \\
Asymp. Sig. (2-tailed) & .200 c,d \\
a. Test distribution is Normal. & \\
b. Calculated from data. & \\
c. Lilliefors Significance Correction. & \\
d. This is a lower bound of the true significance.
\end{tabular}

Sumber:

Berdasarkan hasil pada uji normalitas di atas, uji ini dilakukan dengan menggunakan metode Kolmogorof-Spirnov test. Diketahui hasil signifikansi pada uji normalitas yaitu sebesar 0,2. Hal ini menunjukkan bahwa hasil tersebut lebih besar dari taraf signifikansi sebesar 0,05. Sehingga dapat disimpulkan bahwa uji normalitas pada penelitian ini berdistribusi normal.

\section{Uji Paired Sampel T-test}

Untuk menguji ada perbedaan atau tidak dari pengaruh bermain peran terhadap 
interaksi sosial anak sebelum dan sesudah diberikan perlakuan maka dilakukan uji paired sampel t-test dengan SPPS versi 23. Penelitian ini menggunakan taraf signifikansi $5 \%$ atau 0,05 berdasarkan hipotesis penelitian yang telah ditetapkan, maka kriteria pengujian dalam uji-t adalah sebagai berikut :

Jika nilai signifikan $<0,05$ maka $\mathrm{H}_{0}$ ditolak dan $\mathrm{H}_{\mathrm{a}}$ diterima atau ada perbedaan atau pengaruh.

Jika nilai signifikan $>0,05$ maka $\mathrm{H}_{0}$ diterima dan $\mathrm{H}_{\mathrm{a}}$ di tolak atau tidak ada perbedaan atau pengaruh.

Hasil uji paired sampel t-test dengan melalui analisis SPSS, dapat diketahui perbedaan pengaruh bermain peran terhadap interaksi sosial anak sebelum dan sesudah diberikan perlakuan dapat ditunjukkan pada tabel dibawah ini :

Tabel

\section{Uji Paired Sampel T-test}

\begin{tabular}{|c|c|c|c|c|c|c|c|c|c|}
\hline & \multicolumn{5}{|c|}{$\begin{array}{c}\text { Paired } \\
\text { Differences }\end{array}$} & \multirow{3}{*}{$\mathrm{t}$} & \multirow{3}{*}{ df } & \multirow{3}{*}{$\begin{array}{l}\text { Sig. } \\
(2- \\
\text { tailed })\end{array}$} \\
\hline & & \multirow[t]{2}{*}{ Mean } & \multirow[t]{2}{*}{$\begin{array}{c}\text { Std. } \\
\text { Deviatio } \\
\mathrm{n}\end{array}$} & \multirow[t]{2}{*}{$\begin{array}{l}\text { Std. } \\
\text { Error } \\
\text { Mean }\end{array}$} & \multicolumn{2}{|c|}{$\begin{array}{l}95 \% \text { Confidence } \\
\text { Interval of the } \\
\text { Difference }\end{array}$} & & & \\
\hline & & & & & Lower & Upper & & & \\
\hline Pair 1 & $\begin{array}{l}\text { Pre-test - } \\
\text { Post-test }\end{array}$ & -15.400 & 4.083 & .913 & $\begin{array}{l}- \\
17.311\end{array}$ & -13.489 & -16.866 & 19 & .000 \\
\hline
\end{tabular}

Sumber: Olah data Penelitian

Berdasarkan hasil perhitungan dengan menggunakan bantuan aplikasi SPSS versi 23 maka diperoleh data yaitu nilai signifikansi lebih kecil dari 0,05 yaitu 0,000, maka dapat disimpulkan bahwa terdapat penolakan terhadap $\mathrm{H}_{0}$ dan $\mathrm{H}_{\mathrm{a}}$ diterima maka dapat disimpulkan bahwa " Ada pengaruh atau ada perbedaan antara bermain peran terhadap interaksi sosial anak setelah dan sebelum diberi perlakuan".

Pada pembahasan ini akan dikaji adanya pengaruh bermain peran terhadap interaksi sosial anak usia dini kelas A1 dengan jumlah sampel 20 siswa. Sampel tersebut diambil dari kelas A. Dari kelas A yang terdiri dari 3 kelas yaitu kelas A1, A2 dan A3 diambil kelas A1 sebagai kelas penelitian. Sebelumnya 20 siswa tersebut diberikan pre-test untuk mengetahui interaksi sosial anak sebelum diberikan bermain peran. Setelah itu diberikan perlakuan berupa bermain peran, kemudian diberikan 
post-test untuk mengetahui apakah ada pengaruh metode bermain peran terhadap interaksi sosial anak.

Berdasarkan hasil analisis data yang dilakukan analisis deskriptif dilakukan untuk menguraikan kecenderungan hasil kecakapan responden dari interaksi sosial anak yang diberikan dengan menggunakan metode bermain peran dan yang tidak diberikan metode bermain peran. Rangkuman analisis deskriptif pada tabel 4.1 yaitu pretest dan 4.2 yaitu posttest dapat disimpulkan bahwa nilai minimum pada pretest yaitu 40 dan maksimum yaitu 54 dengan rata-rata sebesar 45.55 kemudian untuk posttest nilai minimum yaitu 58 dan nilai maksimum 66 dengan rata-rata 60.95 jika dilihat dari statistik analisis deskriptif dapat disimpulkan bahwa kemampuan interaksi sosial anak lebih meningkat ketika diberi perlakuan berupa bermain peran dari sebelum diberi perlakuan. Kemudian adapun hasil yang diperoleh dari standar deviasi yaitu pretest sebesar 5.226 dan posttest yaitu 2.373 hal ini berarti data yang diperoleh menyebar dan tidak terpusat pada nilai tertentu. Jadi dapat disimpulkan lagi bahwa interaksi sosial anak mengalami peningkatan yang lebih baik dengan diberikannya metode bermain peran. Hal tersebut terlihat dari hasil analisis deskriptif yang dilakukan menggunakan bantuan aplikasi SPPS 23.

Berdasarkan hasil analisis data menggunakan uji t-test atau uji paired sampel ttest menggunakan bantuan SPSS maka hasil yang diperoleh bahwa nilai signifikansi lebil kecil dari 0,05 atau sig. $<0,05$ maka $\mathrm{H}_{0}$ di tolak dan $\mathrm{H}_{\mathrm{a}}$ di terima. Hal ini berarti bahwa bermain peran mempengaruhi interaksi sosial anak usia dini RA Thoriqul Ulum kelas A. Hasil perolehan data diatas dipengaruhi karena bermain peran memberikan pengalaman kepada anak untuk menjadi seseorang dan merasakan apa yang menjadi perannya sesuai dengan daya khayalannya. Dengan bermain peran, anak mampu mengutarakan gagasan, ide-idenya dengan leluasa sesuai dengan peran yang dimainkan. Hal ini membuat interaksi sosial anak semakin berkembang.

\section{KESIMPULAN}

Berdasarkan hasil analisis data yang telah dilakukan, serta pembahasan yang telah di sajikan peneliti menarik suatu kesimpulan bahwa: Kemampuan interaksi sosial anak setelah diberikan perlakuan berupa bermain peran mengalami peningkatan yang baik, interaksi sosial anak lebih baik dari sebelumnya seperti yang telah dipaparkan 
dalam hasil analisis deskriptif, dengan bermain peran anak dapat berinteraksi dengan baik dan dapat bergaul dengan teman-temannya dengan baik.

Terdapat pengaruh yang signifikan antara metode bermain peran dengan interaksi sosial anak di RA Thoriqul Ulum Sajen. Hal ini terlihat dari rata-rata interaksi sosial anak sebelum dan sesudah diberi perlakuan adalah dari 45.55 menjadi 60.95. Hal ini juga dibuktikan dari hasil uji hipotesis dimana nilai sig. $<0,05$.

\section{REFERENSI}

Ardy Wiyani, Novan dan Barnawi. Format PAUD. Jogjakarta: Ar-Ruzz Media, 2014. Arikunto. Prosedur Peneltian: Suatu Pendekatan Praktek. Jakarta: Rineka Cipta, 2010. Ayuningtiyas, Vera. "Metode Bermain Peran (Role Playing) dalam Upaya Menumbuhkembangkan Keteramapilan Berbicara Bahasa Indonesia pada Anaka Usia Dini di TK Bhayangkari 17 Cimahi". Jurnal Empowerment, Vol.2, No.2, September, Isuue (2013): 50-52. ISSN No. 2252-47738.

Bandi. “Manajemen Pendidikan Anak Usia Dini (PAUD) Untuk Meningkatkan Kualitas Pendidikan di TK Negeri Pringtali, Jatimulyo,Grimulyo, Kulon Progo" Prosiding Seminar Nasional Pendidikan, 2018.

Beckley, Pat. Belajar Pada Anak Usia Dini. Jakarta: Penerbit Indeks Jakarta, 2018. Istiqomah, Laelatul, "Tiga Pilar Kebijakan Pemerintah Dalam Pembinaan PAUD”, Golden Age, Vol. 1 No. 1, April, Issue (2016): 62. e-ISSN: 2502-3519.

Lutifah ,Ulya dan Anita Chandra Dewi Sagala. “Upaya Meningkattkan Interaksi Sosial Melalui Permainan Tradisional Jamuran Pada Anak Kelompok B TK Kuncup Sari Semarang Tahun Ajaran 2014/2015". Jurnal Penelitian PAUDIA.

Mulyasa. Manajemen PAUD. Bandung: PT Remaja Rosdakarya, 2014.

Nur Inten, Dinar. “ Pengembangan Keterampilan Berkomunikasi Anak Usia Dini Melalui Metode Bermain Peran". MediaTor, Vol.10, No.1, Juni, (2017): 111.

Pebriana, Putri Hana. “Analisis Penggunaan Gadget Terhadap Kemampuan Interaksi Sosial Pada Anak Usia Dini", Jurnal Obsesi, Vol.1, No.1, Issue (2017): 4.

Sholichah ,Zumrotus dan Rianto, Yatim. "Penerapan Metode Bermain Peran Untuk Perkembangan Sosial Emosional Anak Usia 5-6 Tahun di Kelompok B UPT SPNF SKB Gresik". Volume 1. No.1, Issue (2012): 6. 
Annisa Rahmilah Bakri, Juli Amaliyah Nasucha , Dwi Bhakti Indri M

Siska, Yulia. "Penerapan Metode Bermain Peran (Role Playing) dalam meningkatkan keterampilan sosial dan keterampilan Berbicara Anak Usia Dini". Edisi khusus No.2, Agustus, Issue (2011): 33. ISSN 1412-565X.

Suyanto, Slamet, Dasar-dasar Pendidikan Anak Usia Dini. Yogyakarta: Penerbit Hikayat Publishing, 2005. 